\title{
SISTEM PENDUKUNG KEPUTUSAN UNTUK MENENTUKAN TINGKAT KECANDUAN GAME ONLINE MENGGUNAKAN METODE SIMPLE ADDITIVE WEIGHTING (SAW)
}

\author{
Rizki Ramadhan', Fitriyani $^{2}$ \\ Sistem Informasi, Fakultas Teknologi Informasi, Universitas Adhirajasa Reswara Sanjaya \\ arizzrrr@gmail.com ${ }^{1}$, fitriyani@ars.ac.id ${ }^{2}$
}

\begin{abstract}
Abstrak
Bermain game online menjadi kegemaran setiap orang dari semua kalangan, baik anak-anak maupun orang dewasa. Game online menjadi idola bagi semua kalangan karena dapat dijadikan alternatif menghilangkan kejenuhan setelah seharian beraktivitas, Sayangnya tidak semua orang dapat mengontrolnya dengan baik hingga menjadi kecanduan terhadap game online. Selain sebagai sarana hiburan game online juga memberikan tantangan yang menarik untuk diselesaikan sehingga seseorang bermain game online tanpa memperhitungkan waktu demi mencapai kepuasan. Seseorang dapat terus menerus bermain game online sampai melupakan waktu bahkan melupakan kondisi lingkungan disekelilingnya. Keseringan dalam bermain game online dapat berdampak pada tingkat kecanduan seseorang terhadap game. Namun, tidak semua orang menyadari bahwa telah memiliki jenis perilaku kecanduan game. Oleh sebab itu, dilakukan penelitian untuk menentukan tingkat kecanduan seseorang terhadap game online. Jenis perilaku tersebut kemudian dibuat ke dalam sebuah sistem pendukung keputusan (SPK) berbasis web. Sistem ini dirancang bangun menggunakan perhitungan metode simple additive weighting (SAW). Dengan dilakukannya penelitian ini, dihasilkan sebuah sistem untuk menentukan tingkat kecanduan game online berdasarkan enam jenis perilaku kecanduan game berdasarkan studi pustaka terdahulu seperti salience, euphoria, conflict, tolerance, withdrawal, relapse and reinstatement. Sistem ini dapat menampilkan hasil perangkingan yang paling banyak memiliki perilaku kecanduan game online berdasarkan hasil peritungan metode simple additive weighting (SAW).
\end{abstract}

Kata kunci : Kecanduan Game, Simple Additive Weighting, Web

\section{Pendahuluan}

Perkembangan dan kemajuan teknologi informasi dan komunikasi yang sangat pesat menuntut kita untuk jeli memilah dan memilih berbagai informasi yang kita terima. Contoh teknologi informasi dan komunikasi yaitu teknologi internet yang saat ini memberikan manfaat yang sangat besar bagi kemajuan di segala bidang. Salah satu dampak dari kemajuan teknologi adalah munculnya perangkat gadget berupa smartphone yang selain berguna sebagai sarana komunikasi juga bisa untuk bermain game (Purnamasari et al., 2019). Salah satu kegunaan internet dapat digunakan untuk menyelesaikan tugas dirumah dari sekolah namun kenyataannya banyak yang beralih pada game online (Harefa \& Marbun, 2020).

Game online salah satunya berfungsi sebagai sarana hiburan. Selain sebagai sarana hiburan, game online berfungsi sebagai sarana sosialisasi. Game online mengajarkan sesuatu yang baru karena adanya frekuensi bermain yang sering. Dengan sering melihat dan bermain game online, maka seseorang akan meniru adegan di dalam game online tersebut (Ulfa, 2017). Penggunaan sebagai sarana hiburan secara berlebihan akan membawa dampak yang negatif. Game online sebenarnya diciptakan untuk mengusir kepenatan atau sekedar refreshing otak. Namun, nyatanya game tersebut malah membuat sang pemain kecanduan (Purnamasari et al., 2019).

Remaja dianggap lebih sering dan lebih rentan terhadap kecanduan game online daripada orang dewasa. Masa remaja yang berada pada periode ketidakstabilan, cenderung lebih mudah terjerumus terhadap percobaan hal-hal baru. Masa remaja juga lekat dengan stereotype periode bermasalah yang memungkinkan percobaan terhadap hal baru tersebut berisiko menjadi perilaku bermasalah. Akibatnya, remaja yang kecanduan game online cenderung kurang tertarik terhadap kegiatan lain, merasa gelisah saat tidak dapat bermain game online, penurunan prestasi akademik, relasi sosial, dan kesehatan. Sebagai contoh, seorang remaja asal Taiwan meregang nyawa setelah bermain game online selama 40 jam tanpa henti. Di Indonesia sendiri, 10 anak di Banyumas didiagnosis mengalami gangguan mental akibat kecanduan game online dan harus mendapat terapi di RSUD Banyumas (Novrialdy, 2019). Sebuah penelitian di Amerika Serikat dilakukan terhadap 963 orang remaja berusia antara 13 dan 18 tahun, menunjukkan bahwa 86 persen dari anak-anak tersebut terlalu banyak menghabiskan waktu untuk bermain video game (Harefa \& Marbun, 2020).

Kecanduan game online membuat pelajar lebih banyak menghabiskan waktu didepan 
komputer sehingga menghambat interaksi dengan teman-teman seusianya, selain itu pelajar akan mengalami ketergantungan pada aktivitas game, dan mengurangi waktu belajar. Kecanduan game online terbentuk oleh faktor internal psikologis dan lingkungan, serta berpotensi menjadi pribadi yang tidak aktif, seperti rasa malu, ketergantungan, depresi, agresi, rendah harga diri, pengendalian diri yang rendah, dan narsisme (Harefa \& Marbun, 2020).

Seseorang yang sudah kecanduan dengan game online maka akan ada gejala yang timbul seperti, salience (berfikir untuk bermain game sepanjang hari), tolerance (jangka bermain yang selalu meningkat), relapse \& reinstatement (cenderung untuk bermain lagi setelah sekian lama tidak bermain), withdrawal (merasa buruk jika tidak dapat bermain game online), dan conflict (bertengkar dikarenakan bermain game secara berlebihan) (Prastyo, 2017). Enam kriteria kecanduan game online ini merupakan pengukuran untuk mengetahui kecanduan atau tidaknya seorang pemain game yang ditetapkan. Pemain yang mendapatkan tiga dari enam kriteria merupakan indikasi pemain yang mengalami kecanduan game online (Purnamasari et al., 2019).

Penelitian terkait pertama yaitu yang dilakukan oleh (Harefa \& Marbun, 2020). Penelitian ini membahas kehadiran game online di tengah-tengah laju teknologi. Variabel input kecanduan terhadap game online terdiri dari tolerance (berkaitan dengan durasi waktu yang digunakan), compulsion (dorongan dari dalam diri sendiri), dan withdrawl (ketidaksanggupan menahan diri) dan variabel output adalah tidak candu, candu dan sangat candu.

Penelitian terkait kedua yaitu artikel penelitian yang dilakukan oleh (Latubessy \& Wijayanti, 2017) dihasilkan sebuah model identifikasi tingkat kecanduan game berdasarkan enam jenis perilaku kecanduan game seperti Salience, Euphoria, Conflict, Tolerance, Withdrawal, Relapse and Reinstatement. Model ini dapat digunakan sebagai dasar dalam pengembangan aplikasi maupun sistem komputer untuk identifikasi tingkat kecanduan game.

Penelitian ini dilakukan untuk menerapkan metode Simple Additive Weighting (SAW) untuk menentukan tingkat kecanduan terhadap game online. Metode Simple Additive Weighting (SAW) merupakan salah satu metode penyelesaian masalah yang sering juga dikenal dengan istilah metode penjumlahan berbobot. Konsep dasar metode SAW adalah mencari penjumlahan terbobot dari rating kinerja pada setiap alternatif dari semua atribut (A. S. Putra et al., 2018). Alasan tersebut menjadikan pembuatan suatu model dalam pengambilan keputusan merupakan hal penting, sehingga keputusan yang diambil merupakan keputusan yang akurat, cermat dan tentu saja menguntungkan bagi yang bersangkutan (Setiawan, 2017). Maka berdasarkan latar belakang di atas, penulis tertarik untuk membuat penelitian yang berjudul "Sistem Pendukung Keputusan Untuk Menentukan Tingkat Kecanduan Game Online Menggunakan Metode Simple Additive Weighting (SAW)".

\subsection{Identifikasi Masalah}

Berdasarkan latar belakang yang telah diuraikan, terdapat permasalahan sebagai berikut:

1. Terdapat beberapa potensi yang akan berdampak bagi seorang pelajar jika sudah kecanduan game, bagaimanakah mengetahui tingkat kecanduan game online pada pelajar?

2. Bagaimana mengimplementasikan metode simple additive weighting (SAW) untuk menentukan tingkat kecanduan terhadap game online?

\subsection{Tujuan Penelitian}

Berdasarkan latar belakang yang telah diuraikan, tujuan penelitian ini adalah :

1. Untuk menentukan tingkat kecanduan terhadap game online pada pelajar khususnya di kota Bandung.

2. Untuk mengimplementasikan metode simple additive weighting (SAW) sehingga dapat mengetahui tingkat kecanduan terhadap game online.

\section{Landasan Teori}

Dalam penelitian ini memiliki pedoman teori-teori yang mendasari permasalahan game online, dan teori-teori untuk menentukan tingkat kecanduan terhadap game online berdasarkan beberapa artikel penelitian terdahulu sehingga penelitian ini akan bermanfaat dan dapat dijadikan sebagai referensi untuk peneliti selanjutnya di bidang yang sama.

\subsection{Metode Simple Additive Weighting}

Metode Simple Additive Weighting (SAW) merupakan salah satu metode penyelesaian masalah yang sering juga dikenal dengan istilah metode penjumlahan berbobot. Metode SAW membutuhkan proses normalisasi matriks keputusan (x) ke suatu skala yang dapat di perbandingkan dengan semua rating alternatif yang ada(A. S. Putra et al., 2018).

Metode SAW dipilih karena mampu menyeleksi alternatif terbaik dari sejumlah alternatif berdasarkan kriteria-kriteria yang telah ditentukan (Setiawan, 2017). Kriteria-kriteria tersebut bersifat dinamis dan nilai setiap bobot kriteria dapat diubah sesuai keinginan pengguna (Suryana et al., 2017).

\subsection{Game Online}

Game online merupakan bagian dari internet yang sering dikunjungi dan sangat digemari dan bisa menyebabkan kecanduan yang memiliki 
intensitas yang sangat tinggi (Latubessy \& Wijayanti, 2017).

Game online adalah media elektronik yang menyuguhkan permainan berupa tampilan gerak, warna, suara yang memiliki aturan main dan terdapat level tertentu, yang bersifat menghibur dan bersifat adiktif. Secara operasional game online adalah sebuah mesin permainan yang memiliki konsep permainan menarik, memiliki gambar tiga dimensi, dan efek-efek yang luar biasa (Adiningtiyas, 2017).

\subsection{Kecanduan Game Online}

Kecanduan merupakan perasaan yang sangat kuat terhadap sesuatu yang diinginkannya sehingga akan berusaha untuk mencari sesuatu yang sangat diinginkan itu, misalnya kecanduan internet, kecanduan melihat televisi, atau kecanduan bekerja. Kecanduan game online merupakan salah satu jenis kecanduan yang disebabkan oleh teknologi internet atau yang lebih dikenal dengan internet addictive disorder (Adiningtiyas, 2017).

Kriteria tingkah laku kecanduan (Prastyo, 2017) sebagai berikut:

1. Salience: menunjukkan dominasi aktivitas bermain game dalam pikiran dan tingkah laku.

2. Euphoria: mendapatkan kesenangan dalam aktivitas bermain game.

3. Conflict: pertentangan yang muncul antara orang yang kecanduan dengan orang- orang yang ada di sekitarnya (external conflict) dan juga dengan dirinya sendiri (internal conflict) tentang tingkat dari tingkah laku yang berlebihan.

4. Tolerance: aktivitas bermain game online mengalami peningkatan secara progresif selama rentang periode untuk mendapatkan efek kepuasan.

5. Withdrawl: perasaan tidak menyenangkan pada saat tidak melakukan aktivitas bermain game.

6. Relapse and Reinstatement: kecenderungan untuk melakukan pengulangan terhadap polapola awal tingkah laku kecanduan atau bahkan menjadi lebih parah walaupun setelah bertahuntahun hilang dan dikontrol.

\subsection{Sistem Pendukung Keputusan}

Beberapa definisi sistem pendukung keputusan menurut para ahli diantaranya (Suryana et al., 2017):

1. Sistem pendukung keputusan adalah sebuah sistem yang mampu memberikan kemampuan pemecahan masalah maupun kemampuan pengkomunikasian untuk masalah dengan kondisi semi terstruktur dan tak terstruktur.

2. Sistem pendukung keputusan merupakan sistem informasi yang menyediakan informasi, pemodelan dan pemanipulasian data yang mampu untuk mendukung analisis data secara ad hoc dan pemodelan keputusan serta berorientasi pada perencanaan masa depan.

3. Sistem pendukung keputusan adalah suatu sistem informasi berbasis komputer yang melakukan pendekatan untuk menghasilkan berbagai alternatif keputusan untuk membantu pihak tertentu dalam menangani permasalahan dengan menggunakan data dan model.

\subsection{Basis Data}

Basis data merupakan kumpulan data yang terdiri dari atribut, entity, dan relationship dari informasi suatu instansi atau perusahaan. Database juga merupakan kumpulan data yang umumnya menggambarkan aktifitas-aktifitas dan pelakunya dalam suatu organisasi (Hendini, 2016).

\subsection{Entity Relationship Diagram (ERD)}

ERD merupakan gambar atau diagram yang menunjukan informasi dibuat, disimpan, dan digunakan dalam sistem bisnis. Entitas menggambarkan jenis informasi yang sama. Entitas digunakan untuk menghubungkan antar entitas yang sekaligus menunjukan hubungan antar data. ERD juga dapat digunakan untuk menunjukan aturanaturan bisnis yang ada pada sistem informasi yang akan dibangun (Simarmata, 2020).

\subsection{Unified Modeling Language}

Menurut Sulianta dalam buku teknik perancangan arsitektur sistem informasi, unifed modeling language (UML) merupakan kumpulan diagram-diagram yang sudah memiliki standar untuk membangun perangkat lunak berbasis objek (Ayu \& Permatasari, 2018).

1. Use Case Diagram

Use Case Diagram merupakan diagram yang harus dibuat pertama kali saat pemodelan perangkat lunak berorientasi objek dilakukan.

2. Activity Diagram

Menurut Hendini, activity diagram menggambarkan workflow (aliran kerja) atau aktivitas dari sebuah sistem atau proses bisnis.

3. Sequence Diagram

Sequence diagram adalah diagram yang dibuat untuk mengetahui alur dari interaksi antar objek. Isi dari sequence diagram harus sama dengan use case dan diagram kelas.

4. Class Diagram

Class diagram dibuat setelah diagram use case dibuat terlebih dahulu. Pada diagram ini harus menjelaskan hubungan apa saja yang terjadi antara suatu objek dengan objek lainnya sehingga terbentuklah suatu sistem aplikasi.

\section{Metodologi Penelitian}

Jenis penelitian yang dilakukan adalah penelitian kuantitatif. Tujuan dari metode kuantitatif adalah untuk mengembangkan model, teori, dan hipotesis yang berkaitan dengan fenomena alam 
(Fitriyani, 2015). Untuk mencapai tujuan dan penelitian yang berguna, ada beberapa tahap atau langkah-langkah yang dilakukan dalam sistem pendukung keputusan berbasis web. Berikut adalah tahapan-tahapan yang dilakukan dalam penelitian.

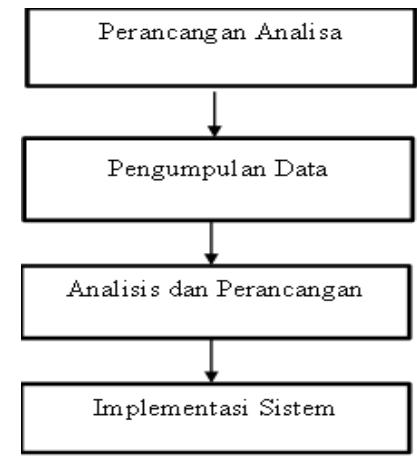

Gambar 1. Tahapan Penelitian

\section{Hasil dan Pembahasan}

Bab ini akan menjelaskan hasil penelitian yang telah dilaksanakan mengenai tingkat kecanduan game online terhadap pelajar menggunakan metode simple additive weighting (SAW).

\subsection{Perancangan Sistem}

Perancangan use case diagram pada aplikasi yang akan dibuat dapat dilihat pada gambar dibawah ini. Proses pengambilan keputusan menggunakan metode SAW diterapkan pada fitur masukkan kriteria, masukkan sub kriteria, masukkan nilai bobot dan masukkan penilaian.

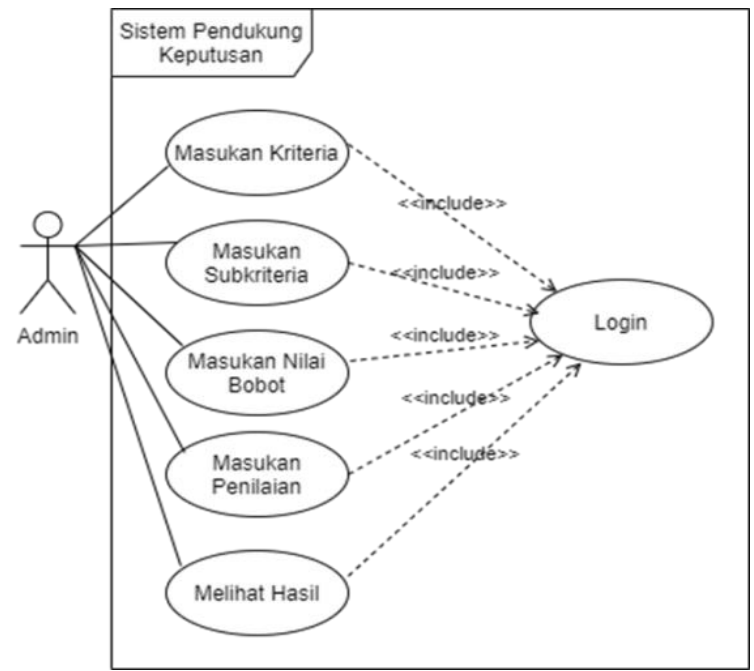

Gambar 2. Use Case Diagram

Aliran kerja digambarkan dengan menggunakan activity diagram. Dimaksudkan untuk memberikan penjelasan mengenai proses dari cara kerja program, mulai dari titik awal, memulai kodisi yang mungkin terjadi, sampai pada titik akhir. Berikut activity diagram dari sistem pendukung keputusan berbasis web.

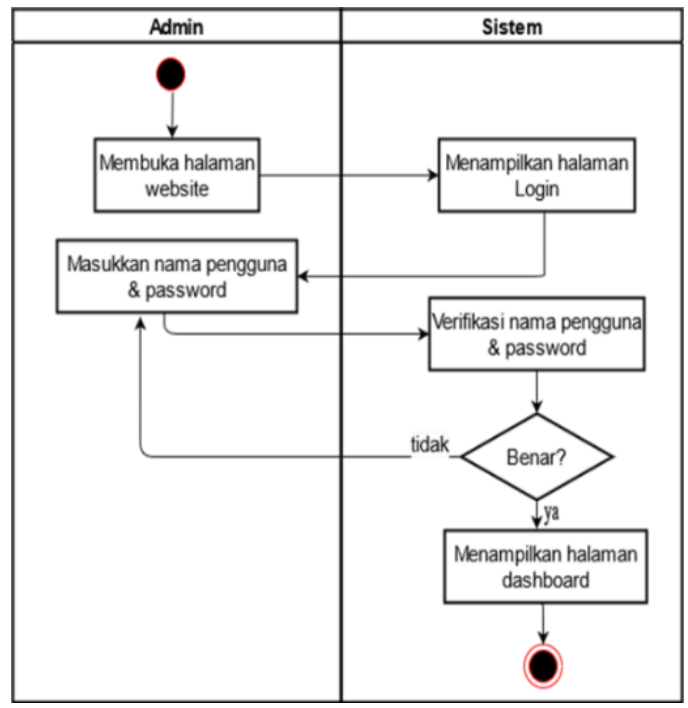

Gambar 3. Activity Diagram Menu Login

Gambar diatas merupakan proses login yang dilakukan oleh administrator berupa activity diagram dimulai dengan masukkan nama pengguna dan password jika valid atau benar maka admin dapat masuk ke halaman beranda.

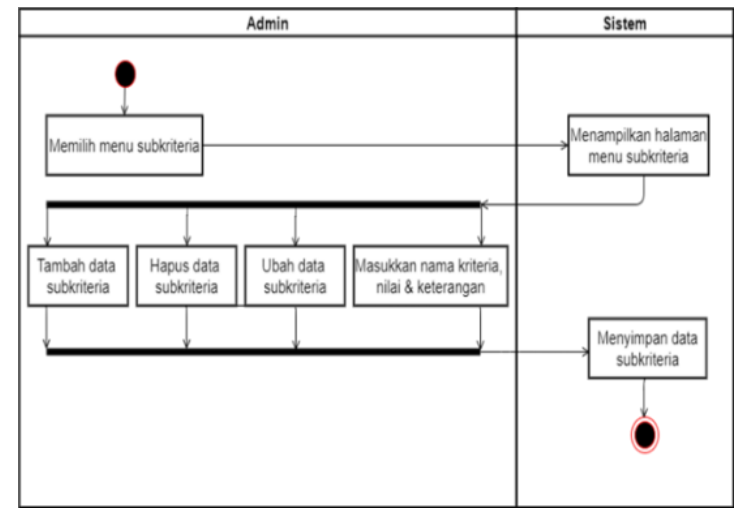

Gambar 4. Activity Diagram Menu SubKriteria

Pada menu subkriteria, administrator dapat menambahkan data subkriteria, menghapus data subkriteria, dan mengubah data subkriteria dengan memasukkan nama kriteria, nilai, dan keterangan.

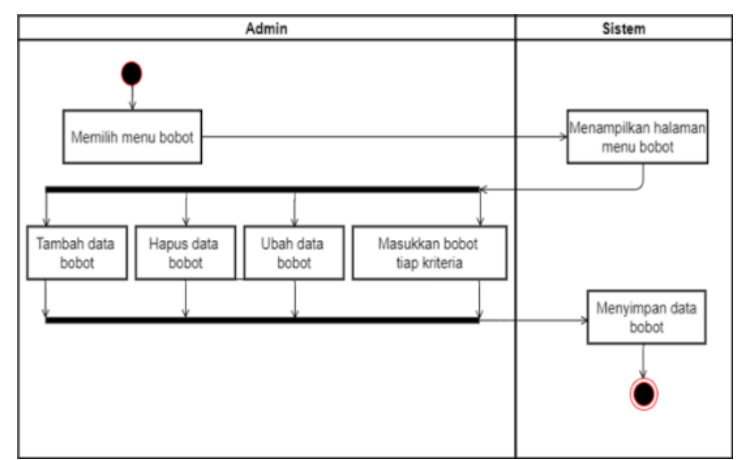

Gambar 5. Activity Diagram Menu Bobot

Pada menu bobot, administrator dapat menambahkan data bobot, menghapus data bobot, dan mengubah data bobot, dengan memasukkan bobot per kriteria. 
JIP (Jurnal Informatika Polinema)

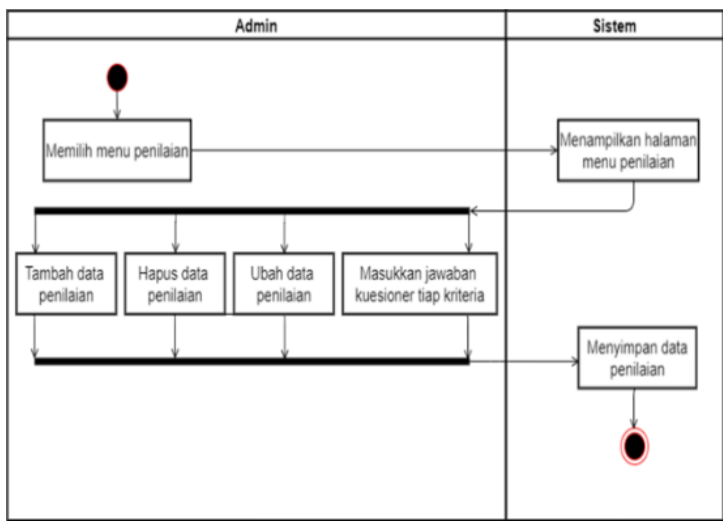

Gambar 6. Activity Diagram Menu Penilaian

Pada menu penilaian, administrator dapat menambahkan data penilaian, menghapus data penilaian, dan mengubah data penilaian dengan memasukkan jawaban kuesioner tiap kriteria.

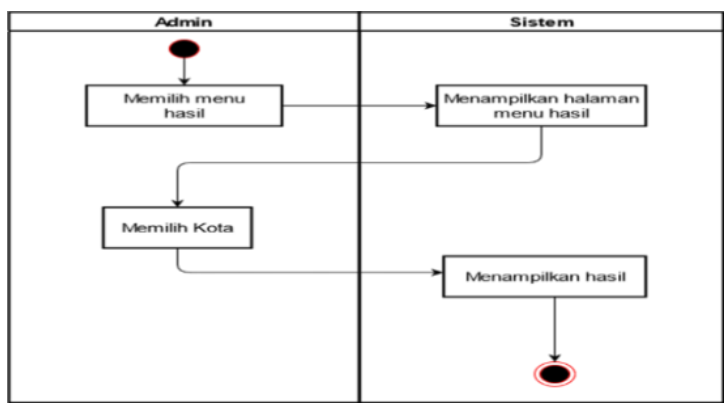

Gambar 7. Activity Diagram Menu Hasil

Pada menu hasil, administrator dapat melihat hasil dengan memilih kota terlebih dahulu kemudian sistem akan dengan otomatis menampilkan hasil penilaian menggunakan perhitungan simple additive weighting (SAW).

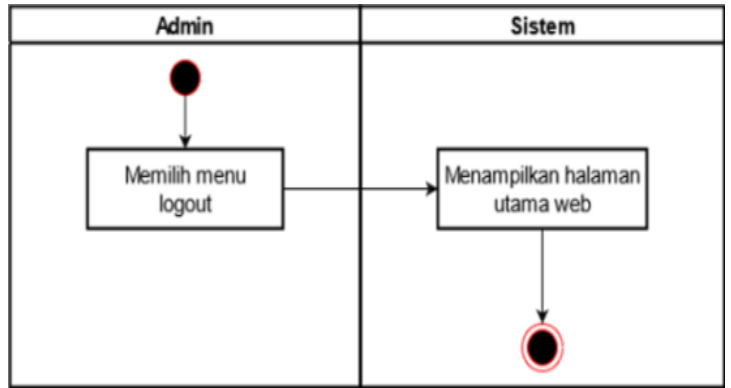

Gambar 8. Activity Diagram Menu Logout

Pada menu logout ketika administrator memilih logout maka sistem akan otomatis menampilan halaman utama web.

Sequence diagram menggambarkan kelakuan objek pada use case dengan mendeskripsikan waktu hidup objek dan pesan yang dikirimkan dan diterima antar objek. Oleh karena itu untuk menggambarkan sequence diagram maka harus diketahui objek-objek yang terlibat dalam sebuah use case beserta metodemetode yang dimiliki kelas. Membuat sequence diagram juga dibutuhkan untuk melihat sekenario yang ada pada use case. Berikut ini adalah sequence diagram sistem pendukung keputusan berbasis web.
ISSN: 2614-6371 E-ISSN: 2407-070X

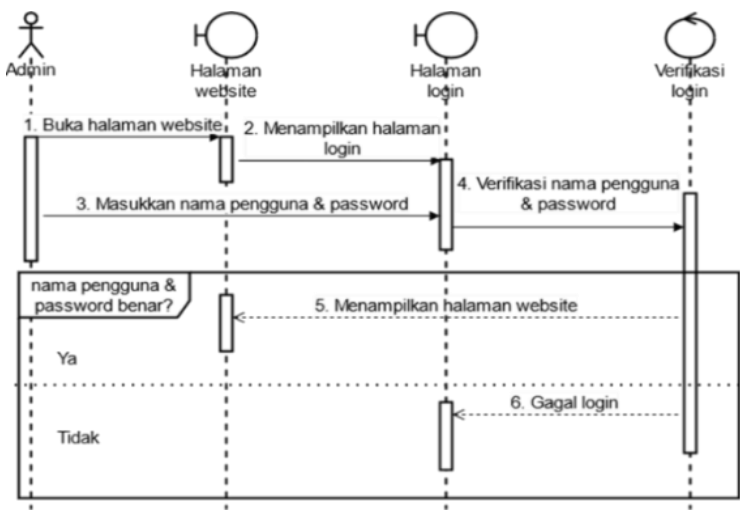

Gambar 9. Sequence Diagram Menu Login

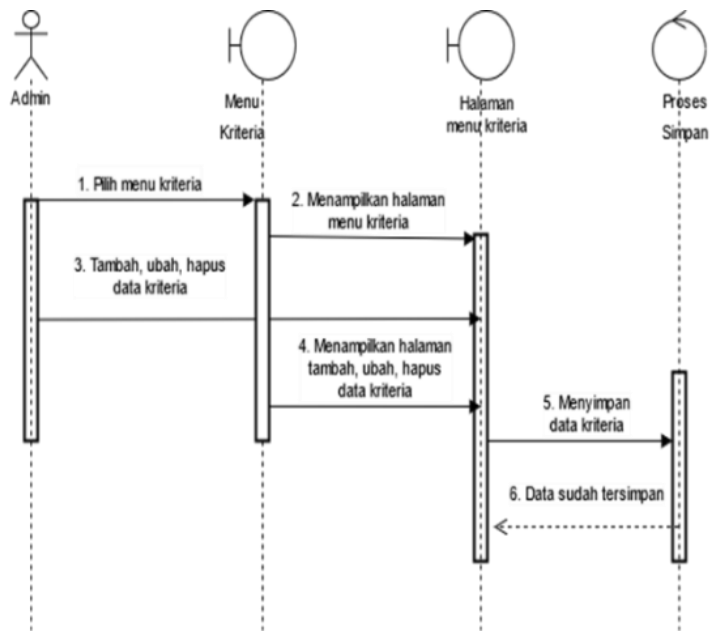

Gambar 10. Sequence Diagram Menu Kriteria

Activity diagram yang kedua menjelaskan proses yang dilakukan di menu kriteria oleh administrator dimana pada menu tersebut administrator dapat menambahkan data kriteria, menghapus data kriteria, dan mengubah data kriteria.

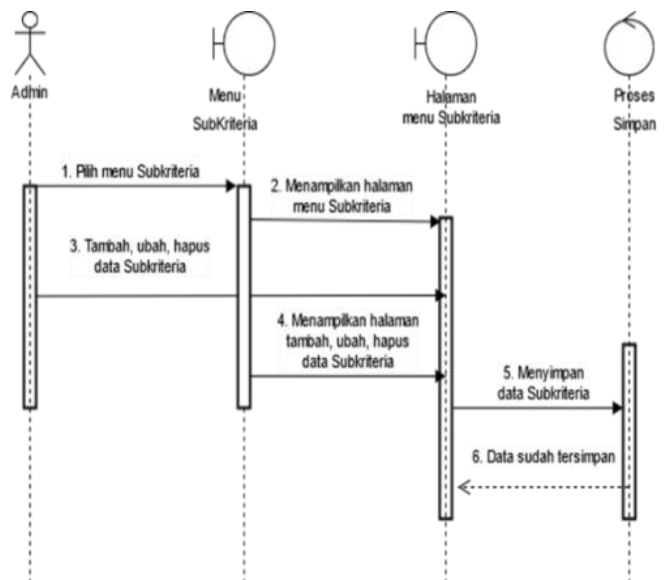

Gambar 11. Sequence Diagram Menu SubKriteria

Sequence diagram menu sub kriteria di atas menjelaskan bahwa admin menambah, mengubah, dan menghapus data sub kriteria di halaman menu sub kriteria, kemudian sistem menyimpan data sub kriteria, jika sudah tersimpan data yang baru ditambah atau diubah akan tampil pada halaman menu sub kriteria. 


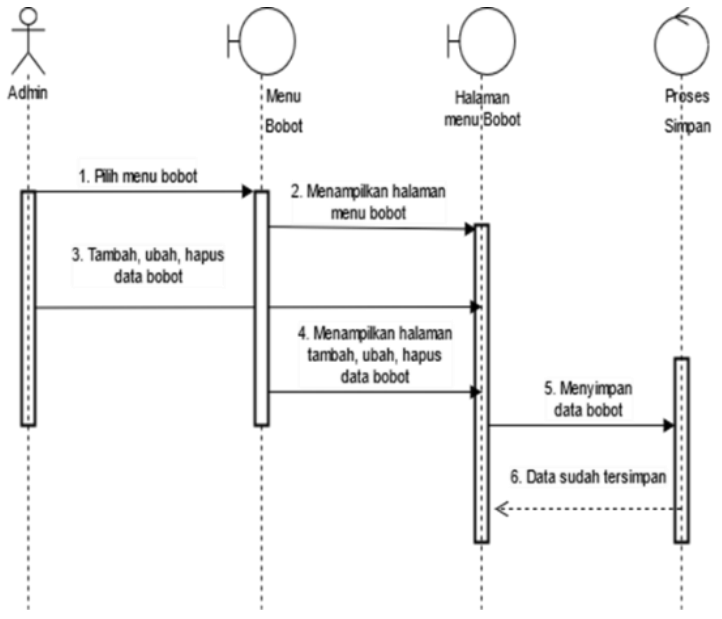

Gambar 12. Sequence Diagram Menu Bobot

Sequence diagram menu bobot di atas menjelaskan bahwa admin menambah, mengubah, dan menghapus data bobot di halaman menu bobot, kemudian sistem menyimpan data bobot, jika sudah tersimpan data yang baru ditambah atau diubah akan tampil pada halaman menu bobot

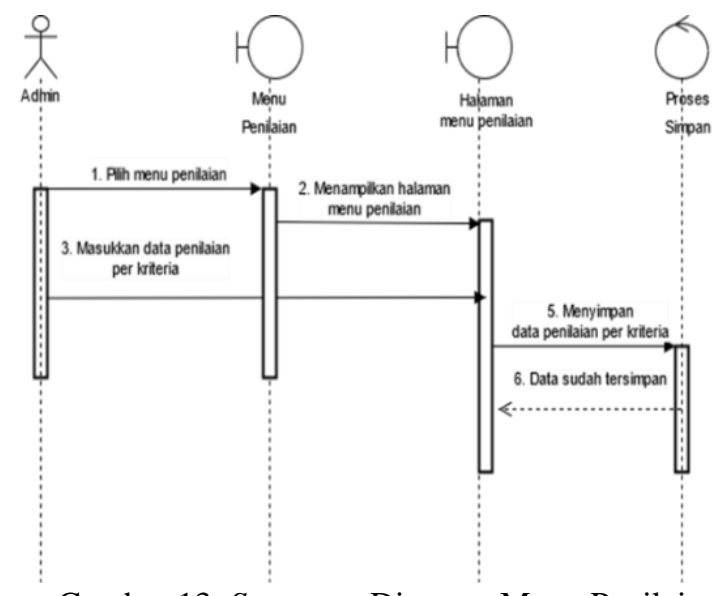

Gambar 13. Sequence Diagram Menu Penilaian

Sequence diagram menu penilaian di bawah menjelaskan bahwa admin menginputkan data penilaian per kriteria di halaman menu penilaian, kemudian sistem menyimpan penilaian per kriteria, jika sudah tersimpan data akan tampil pada halaman menu penilaian.

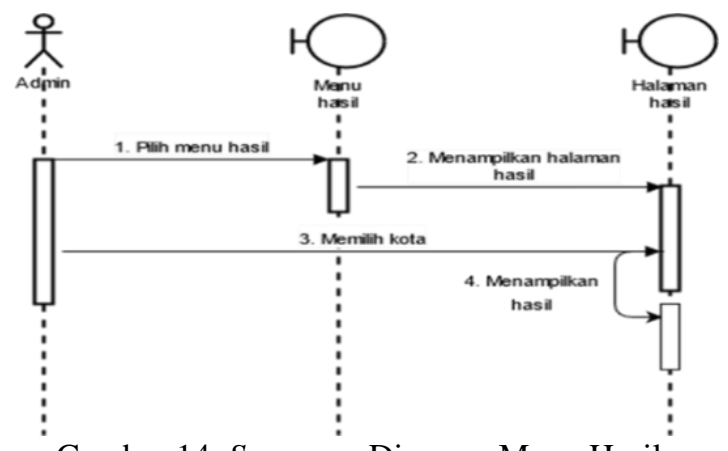

Gambar 14. Sequence Diagram Menu Hasil
Sequence diagram menu hasil di bawah menjelaskan bahwa admin memilih menu hasil dan kota di halaman hasil, kemudian sistem dengan otomatis akan menampilkan hasil perhitungan SAW.

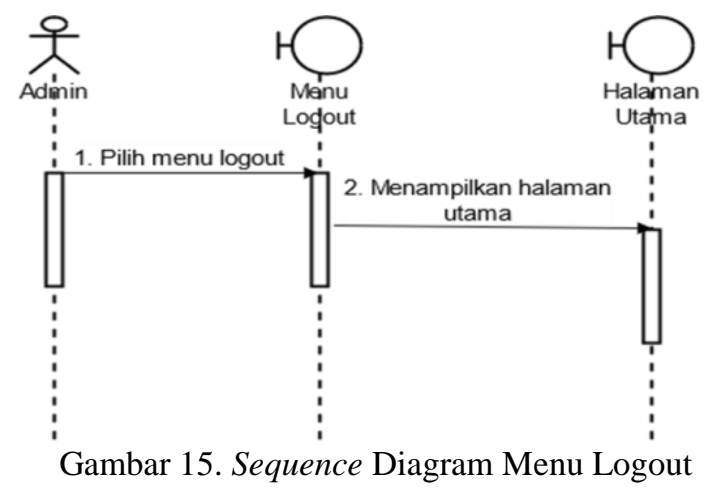

Sequence diagram menu logout di atas menjelaskan bahwa admin memilih menu logout kemudian sistem dengan otomatis akan menampilkan halaman utama.

Class diagram menggambarkan class, atribut, dan objek yang ada pada sistem pendukung keputusan berbasis web pada penelitian ini. Selain itu menggambarkan hubungan satu sama lain seperti pewarisan, containmet, asosiasi, dan lainnya.

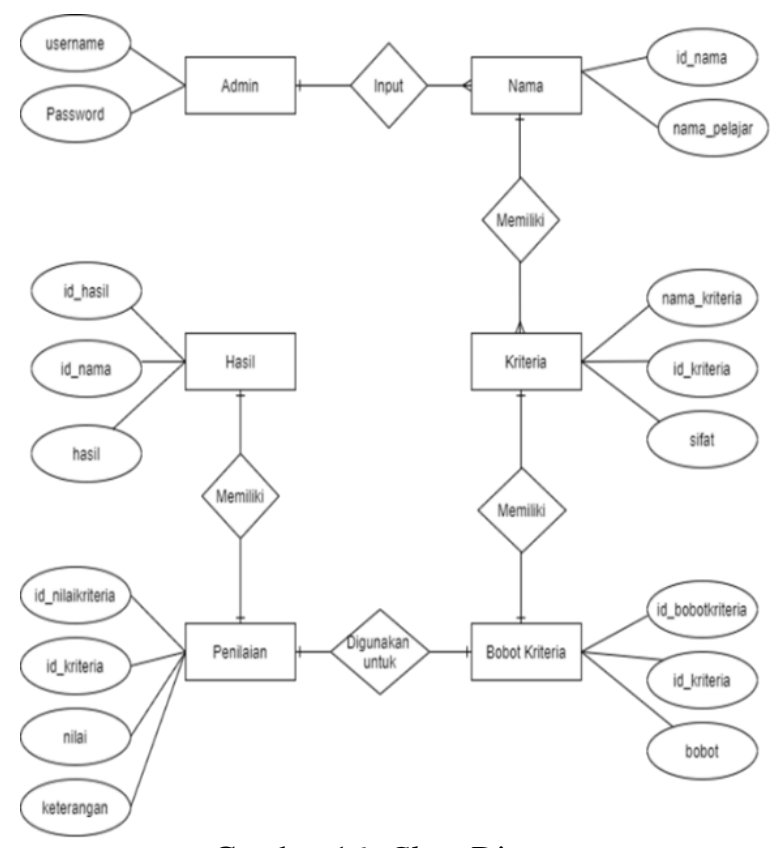

Gambar 16. Class Diagram

Dalam merancang database, ada beberapa metode yang di gunakan, salah satunya adalah dengan menggunakan metode Entity Relationship Diagram atau disingkat dengan istilah ERD (F. K. Putra, 2019). Entity Relationship Diagram (ERD) dapat membantu memvisualisasikan bagaimana data saling terhubung dan berguna untuk mengonstruksi basis data relasional. 


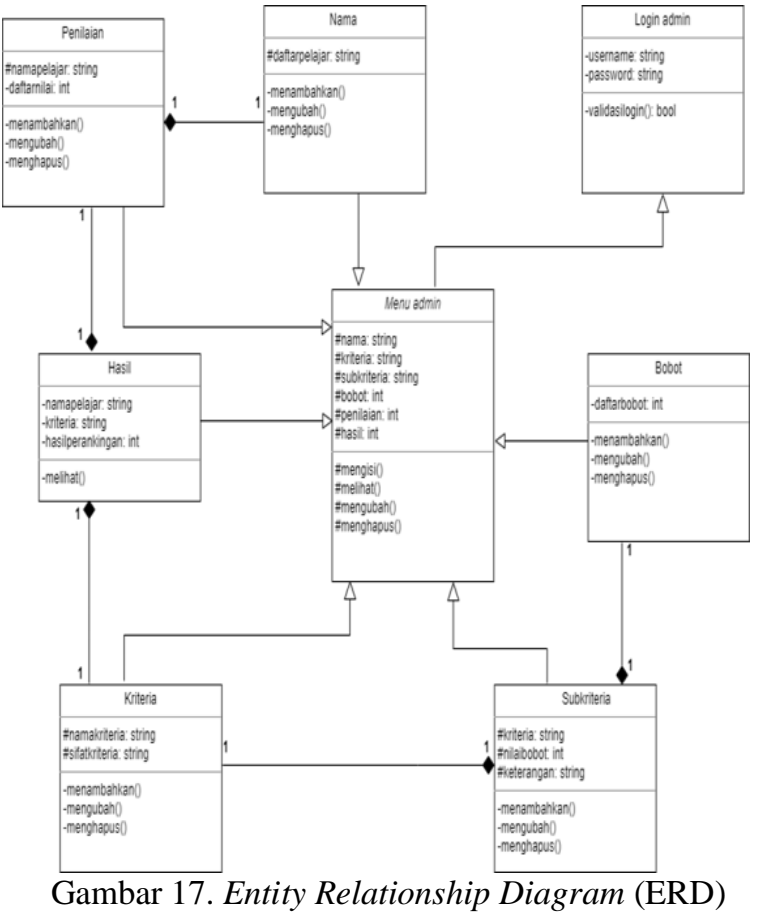

\subsection{Implementasi Sistem}

Implementasi sistem adalah tahap penerapan sekaligus pengujian bagi sistem berdasarkan hasil yang telah dirancang dan sumber kajian pustaka.

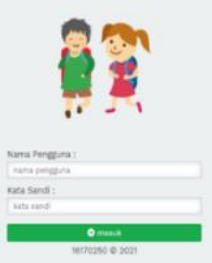

Gambar 18. Halaman Login

Sebagai admin untuk masuk ke dalam sistem, maka harus mengisi nama pengguna dan password yang sesuai. Pada sistem login kredensial di validasi sesuai dengan data yang ada pada basis data

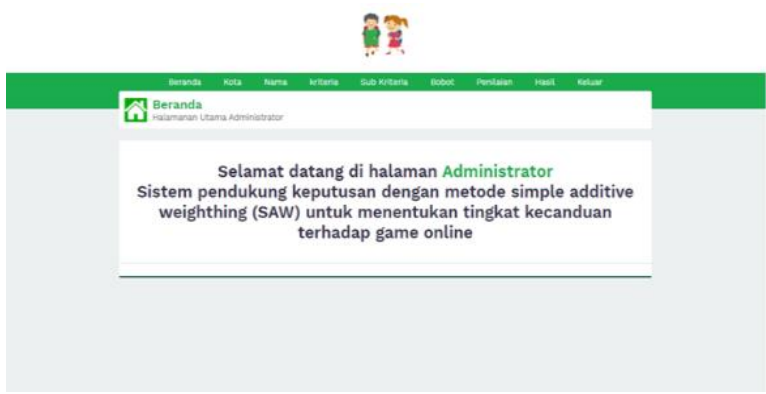

Gambar 19. Halaman Beranda

Halaman beranda merupakan halaman utama setelah admin login. Pada halaman ini, menjelaskan tentang fungsi aplikasi atau sistem yang dibangun

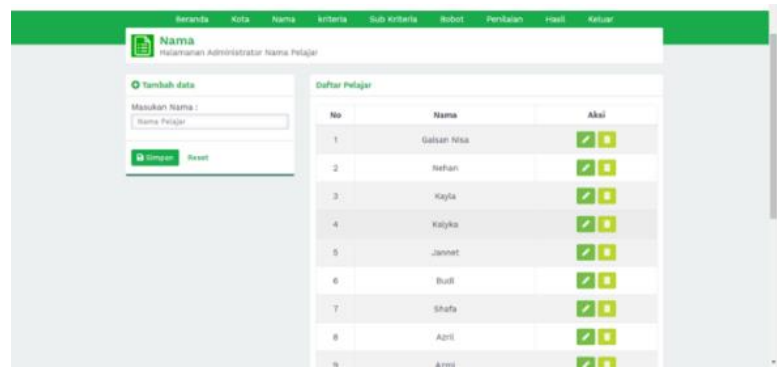

Gambar 20. Halaman Menu Nama

Pada halaman menu kriteria akan menampilkan nama-naam alternatif yang digunakan untuk sistem pendukung keputusan menentukan tingkat kecanduan terhadap game online menggunakan perhitungan simple additive weighting (SAW).

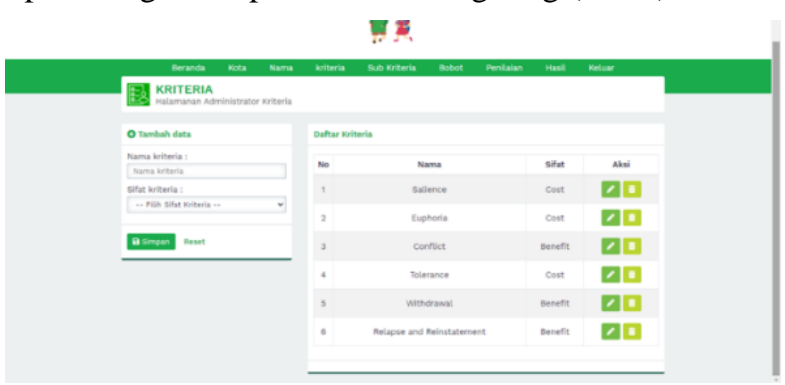

Gambar 21. Halaman Menu Kriteria

Pada halaman menu kriteria akan menampilkan lima perilaku kecanduan terhadap game online yang digunakan sebagai kriteria dalam sistem pendukung keputusan menentukan tingkat kecanduan terhadap game online menggunakan perhitungan simple additive weighting (SAW).

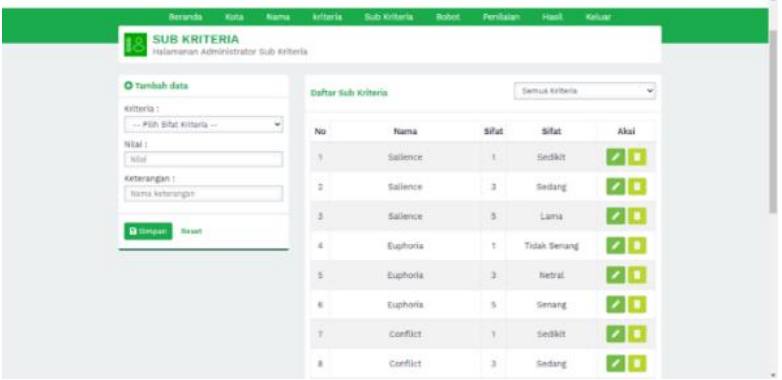

Gambar 22. Halaman Menu SubKriteria

Pada halaman menu sub kriteria akan menampilkan sub cript yaitu nilai bobot tiap kriteria yang digunakan untuk sistem pendukung keputusan menentukan tingkat kecanduan terhadap game online menggunakan perhitungan simple additive weighting (SAW).

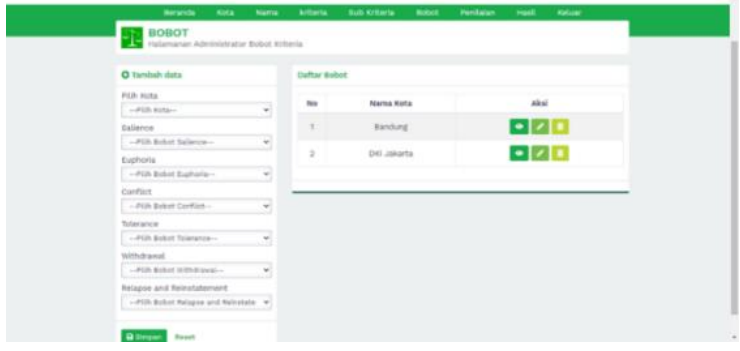

Gambar 23. Halaman Menu Bobot 
Pada halaman menu bobot akan menampilkan daftar bobot selain itu admin dapat memilih nilai bobot sesuai hasil kuesioner pada sistem pendukung keputusan menentukan tingkat kecanduan terhadap game online menggunakan perhitungan simple additive weighting (SAW).

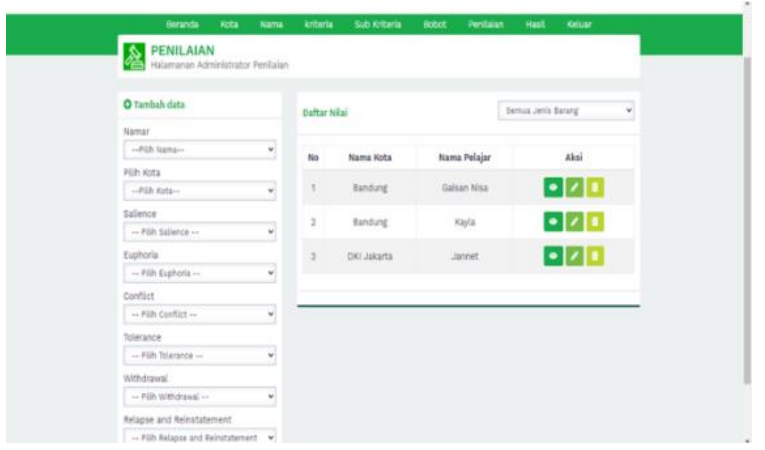

Gambar 24. Halaman Menu Penilaian

Pada halaman menu penilaian akan menampilkan daftar nilai sesuai hasil kuesioner pada sistem pendukung keputusan menentukan tingkat kecanduan terhadap game online menggunakan perhitungan simple additive weighting (SAW).

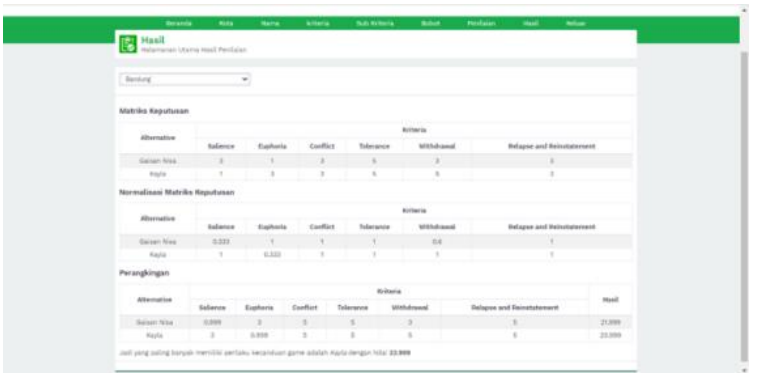

Gambar 25. Halaman Menu Hasil

Pada halaman hasil akan menampilkan hasil akhir dari tahap perhitungan simple additive weighting (SAW).. Selain itu, menampilkan kesimpulan terhadap responden yang mengisi kuesioner.

\section{Penutup}

\subsection{Kesimpulan}

Berdasarkan penelitian yang telah dilaksanakan, maka dapat disimpulkan bahwa penerapan metode simple additive weighting (SAW) dapat diterapkan untuk mengidentifikasi tingkat kecanduan terhadap game online dengan hasil berupa perankingan. Analisis penelitian yang dimulai dengan pengisian kuesioner sampai proses perhitungan simple additive weighting (SAW) memberikan hasil yang cukup tepat dan akurat dalam perankingan individu yang sudah kecanduan game.

Penelitian ini menggunakan enam jenis perilaku kecanduan game, yaitu salience, euphoria, conflict, tolerance, withdrawal, relapse and reinstatement dan dua belas gejala kecanduan game berdasarkan penelitian yang dilakukan oleh (Prastyo, 2017). Namun, gejala - gejala tersebut masih dapat diperluas dan disesuaikan dengan jenis perilaku kecanduan game yang ada.

Dalam penelitian tentang kualitas pelayanan ini hanya dilakukan dengan metode simple additive weighting (SAW), untuk lebih lanjutnya mungkin dapat dilakukan dengan kombinasi metode yang lain seperti dengan metode technique for others reference by similarity to ideal solusiton (TOPSIS).

\section{Daftar Pustaka:}

Adiningtiyas, S. W. (2017). Peran Guru Dalam Mengatasi Kecanduan Game Online. KOPASTA: Jurnal Program Studi Bimbingan Konseling, 4(1), 28-40. https://doi.org/10.33373/kop.v4i1.1121

Ayu, F., \& Permatasari, N. (2018). perancangan sistem informasi pengolahan data PKL pada divisi humas PT pegadaian. Jurnal Infra Tech, 2(2),

12-26. http://journal.amikmahaputra.ac.id/index.php/J IT/article/download/33/25

Fitriyani. (2015). INTEGRASI BAGGING DAN GREEDY FORWARD SELECTION PADA PREDIKSI CACAT SOFTWARE MENGGUNAKAN NAÏVE BAYES. 1-27.

Harefa, N., \& Marbun, M. (2020). IMPLEMENTASI LOGIKA FUZZY MAMDANI UNTUK MENGIDENTIFIKASI. 4(2), 128-138.

Hendini, A. (2016). PEMODELAN UML SISTEM INFORMASI MONITORING PENJUALAN DAN STOK BARANG (STUDI KASUS: DISTRO ZHEZHA PONTIANAK). Khatulistiwa Informatika, 23(2), 201-205. https://doi.org/10.2135/cropsci1983.0011183x $002300020002 x$

Latubessy, A., \& Wijayanti, E. (2017). Model Identifikasi Kecanduan Game Menggunakan Backward Chaining. Simetris: Jurnal Teknik Mesin, Elektro Dan Ilmu Komputer, 8(1), 914. https://doi.org/10.24176/simet.v8i1.807

Novrialdy, E. (2019). Kecanduan Game Online pada Remaja: Dampak dan Pencegahannya. Buletin Psikologi, 27(2), 148. https://doi.org/10.22146/buletinpsikologi.4740 2

Prastyo, Y. (2017). Pembagian Tingkat Kecanduan Game Online Menggunakan K-Means Clustering Serta Korelasinya Terhadap Prestasi Akademik. Elinvo (Electronics, Informatics, and Vocational Education), 2(2), 138-148. https://doi.org/10.21831/elinvo.v2i2.17307

Purnamasari, I., Setiani, E. D., Nurliawati, E., \& Ramadhan, G. (2019). Analisis Dampak Game Online Terhadap Indeks Prestasi Kumulatif (IPK) Pada Mahasiswa/i Pendidikan 
Matematika Universitas PGRI Yogyakarta. Analisis Dampak Game Online Terhadap Indeks Prestasi Kumulatif (IPK) Pada Mahasiswa/i Pendidikan Matematika Universitas PGRI Yogyakarta, 1-9.

Putra, A. S., Aryanti, D. R., \& Hartati, I. (2018). Metode SAW (Simple Additive Weighting) sebagai Sistem Pendukung Keputusan Guru Berprestasi ( Studi Kasus: SMK Global Surya). Prosiding Seminar Nasional Darmajaya, $\quad$ l(1), 85-97. https://jurnal.darmajaya.ac.id/index.php/PSND /article/view/1233/763

Putra, F. K. (2019). Disain Database Untuk Pengelolaan Data Kuliah Kerja Nyata (Kkn) Pada Institut Agama Islam Negeri (Iain) Batusangkar. Jurnal Simtika, 2(1), 60-65.
Setiawan, A. (2017). Implementasi Metode SAW Dalam Penerimaan Siswa Baru Pada SMA Negeri 16 Medan. Jurasik (Jurnal Riset Sistem Informasi Dan Teknik Informatika), 2(1), 96. https://doi.org/10.30645/jurasik.v2i1.23

Simarmata, S. (2020). Perancangan Sistem Informasi Pengelolaan Data Dan Transaksi Berbasis Web Pada Cv . Pangkas Rambut Babe. 4, 203-209.

Suryana, A., Yulianto, E., \& Pratama, K. D. (2017). Perancangan Sistem Pendukung Keputusan Penilaian Prestasi Pegawai Menggunakan Metode Saw, Ahp, Dan Topsis. Jurnal Ilmiah Teknologi Informasi Terapan, 3(2), 130-139. http://jitter.widyatama.ac.id/index.php/jitter/art icle/view/216

Ulfa, M. (2017). Effect of Addiction Online Game Center. Jom. Fisip, 4(1), 1-13. 
Volume 8, Edisi 2, Februari 2022

$36 \mid \mathrm{H}$ a 1 a $\mathrm{m}$ a $\mathrm{n}$ 